\title{
Freedom of Speech - Should Speech that Causes Harm be Free? An International and South African Perspective
}

\author{
Pierre du Plessis
}

University of Johannesburg

pierredp@uj.ac.za

\section{Doi:10.5901/mjss.2014.v5n23p1363}

\begin{abstract}
Freedom of speech is the concept of being able to speak freely without censorship. It is often regarded as an integral concept in modern liberal democracies. If the liberty to express oneself is not highly valued, as has often been the case, there is no problem : freedom of expression is simply curtailed in favour of other values. Free speech becomes a volatile issue when it is highly valued because only then do the limitations placed upon it become controversial. The first thing to note in any sensible discussion of freedom of speech is that it well have to be limited. Every society place some limits on the exercise of speech because speech always takes place within a context of competing values. Stanley Fish (1994)1 is correct when he says that there is no such thing as free speech. Free speech is simply a useful term to focus our attention on a particular form of human interaction and the phrase is not meant to suggest that speech should never be interfered with. No society has yet existed where speech has not been limited to some extent.
\end{abstract}

Keywords: free speech, hate speech, teachers, international law, South African law, schools

\section{Introduction}

The right to freedom of speech is guaranteed under international law through numerous human rights instruments, notably under Article 19 of the Universal Declaration of Human Rights and Article 10 of the European Convention on Human Rights, although implementation remains lacking in many countries. In South Africa the Bill of Rights in the South African Constitution follows the trend in international human rights documents, which restricts the right to freedom of expression by prohibiting the incitement of racial discrimination or racial hatred or hostility.

The synonymous term freedom of expression is sometimes preferred, since the right is not confined to verbal speech but is understood to protect only act of seeking, receiving and imparting information or ideas regardless of the medium used. ${ }^{2}$ (Jacobson, 1995).

In practice, the right to freedom of speech is not absolute in any country, although the degree of freedom varies greatly. Industrialized countries also have varying approaches to balance freedom with order. For instance, the United States First Amendment theoretically grants absolute freedom, placing the burden upon the state to demonstrate when (if ever) censorship is necessary. Canadian law places the burden upon the individual to demonstrate how the speech benefits the public (e.g. hate speech is illegal), and the European Convention on Human Rights guarantees freedom outside specific circumstances in which it prescribes censorship (e.g. to protect national security).

In most liberal democracies, it is generally recognized that restrictions should be the exception and free expression the rule; nevertheless, compliance with this principle is often lacking. The right to freedom of speech is not a right to cause others to live in fear of suffering harm. A decent person knows this and will not speak in ways that threaten others who, themselves, do not mean to do any harm.

\section{Theoretical Rationale for Freedom of Speech}

It is important to understand the various theoretical rationales for freedom of speech if we are to form views about the concept's true nature and its rational limits. In part, the justification for free speech is a general liberal or libertarian presumption against coercing individuals from living how they please and doing what they want. However, a number of more specific justifications are commonly proposed for freedom of speech.

1 Stanley Fish, 1994.

2 Jacobson, 1995). 
For example, Justice McLachlan of the Canadian Supreme Court identified the following in R. v. Keegstra ${ }^{3}$, a 1990 case on hate speech: (1) free speech promotes "The free flow of ideas essential to political democracy and democratic institutions" and limits the ability of the state to subvert other rights and freedoms; (2) it promotes a marketplace of ideas, in which includes, but is not limited to, the search for truth; (3) it is intrinsically valuable as part of the self-actualisation of speakers and listeners; and (4) it is justified by the dangers for good government of allowing its suppression.

Such reasons perhaps overlap. Together, they provide a widely accepted rationale for the recognition of freedom of speech as a basic School of civil liberty.

Each of these justifications can be elaborated in a variety of ways and some may need to be qualified. The first and fourth can be bracketed together as democratic justifications, or a justification relating to self-governance. They relate to aspects of free speech's political role in a democratic society. The second is related to the discovery of truth. The third relates most closely to general libertarian values but stresses the particular importance of language, symbolism and representation for our lives and autonomy.

The Constitution of South Africa contains a Bill of Rights which protects certain rights against the unrestricted exercise of government powers, and the legislature, the executive, the judiciary and other organs of state - even individuals under certain circumstances are bound by the Bill of Rights.

The right to freedom of expression, which can be regarded as one of the essential foundations of a democratic society ${ }^{4}$, is one of the fundamental rights entrenched in the Bill of Rights.

Expression is seen as a means of fulfillment of the human personality, and is closely related to other fundamental rights and freedoms, such as freedom of religion, belief and opinion, the right to dignity, the right to freedom of association and the right to assembly. One of the goals of freedom of expression is therefore to assist in the democratic decision-making and to aid the process of stability and change in society (Burns). verbal. $^{5}$

Section 16 (1) of the South African Constitution protects free expression generally. Freedom of expression includes

This analysis suggests a number of conclusions. First, there are powerful overlapping arguments for free speech as a basic political principle in any liberal democracy. Second, however, free speech is not a simple and absolute concept but a liberty that is justified by even deeper values. Third, the values implicit in the various justifications for free speech may not apply equally strongly to all kinds if speech in all circumstances.

\section{International and Foreign Law on Free Speech}

The right to freedom of expression is universally recognized and most countries if not all impose some form of restrictions on that right. International instruments also provide for that right and recognise the need to strike a balance between the harm caused by hate speech and restrictions to the freedom of expression.

The attitude of the international community is spelled out in the Universal Declaration of human Rights, which provides for the right to the freedom of opinion and expression, including the freedom to compare information and ideas through any media. Similarly, the United Nations Convention on the Elimination of all forms of Racial Discrimination while allowing freedom of expression introduces an obligation on states to declare as a criminal offence the "dissemination of ideas based on racial discrimination".

A more binding instrument, the International Covenant on Civil and Political Rights of 1966, while providing for the freedom of expression modifies it by imposing "special duties and responsible duties". Article $20(2)^{6}$ of that Covenant states that:

"Any advocacy of national, racial or religious hatred that constitutes incitement or discrimination, hostility or violence shall be prohibited by law"

In the European arena the European Commission on Human Rights also allows for the freedom of expression but stipulates that the right carries with it duties and responsibilities and is subject to restrictions and penalties as are described by law and are necessary in a democratic society.

\footnotetext{
${ }^{3}$ R. v. Keegstra.

${ }^{4}$ Van Wyk, 2002:1.

${ }^{5}$ Section 16 (1) of the South African Constitution.

${ }^{6}$ Article 20(2).
} 
In the Handyside ${ }^{7}$ case the court stated that this freedom is applicable not only to information or ideas that are "favourably received or regarded as inoffensive or as a matter of indifference, but also to those that offends, shock or disturb the state or any sector of the population".

\subsection{The Canadian Situation}

Hate speech restrictions are also found in other democracies. The Canadian Supreme Court has accepted controls on hate speech as legitimate and therefore offers us comparable jurisprudence. In terms of section $2(\mathrm{~b})^{8}$ of the Canadian Charter of rights, everyone is guaranteed the freedom of expression. However hate propaganda is prohibited by the Criminal Code, which states that "any person who willfully promotes hatred against "any section of the public distinguished by colour, race, religion or ethic origin" commits an offence. There is no reference to "incitement of imminent violence." The Canadian Supreme Court in the Kiegstra judgement dealt with an accused teacher who made Anti-Semitic statements to his students. Although he was found guilty (by a narrow on the basis that there was a willful promotion of hatred) the court said that the right to freedom of expression covered all messages, "however unpopular, distasteful or contrary to the mainstream". In the same case the court stated that the Criminal Code, which prohibited hate speech, was a reasonable and justifiable limitation on the right to freedom of expression.

In the landmark Supreme Court of Canada case ${ }^{9}$, the court struck down a provision in the Criminal Code of Canada that prohibited publication of false information or news, stating that it violated section 2(b) of the Charter:

In April, 2004, a bill was passed which includes as hate speech propaganda against people based or their sexual orientation. It is now illegal to publicly incite hatred against people based on their colour, race, religion, ethic origin, and sexual orientation. However, under section 319 on hate speech a person cannot be convicted of hate speech "if the person can establish that the statements made are true.

Other laws that protect freedom of speech in Canada, include the Implied Bill of Rights and the Canadian Bill of Rights.

\subsection{United States}

In the United States freedom of expression is protected by the First Amendment to the United States Constitution. There are several exceptions to this general rule, including copyright protection, the Miller ${ }^{10}$ test for obscenity and greater regulation of so-called commercial speech, such as advertising. The Miller test in particular rarely comes into effect.

Neither the federal nor state government engages in preliminary censorship of movies. However, the Motion Picture Association of America has a rating system, and movies not rated by the MPAA cannot expect anything but a very limited release in theatres, making the system almost compulsory.

Within the U.S., the freedom of speech also varies widely from one state to the next. Of all states, the state of California permits its citizens the broadest possible range of free speech under the state constitution (whose declaration of rights includes a strong affirmative right to free speech in addition to a negative right paralleling the federal prohibition on laws that abridge the freedom of speech).

More specifically, through the Pruneyard case ${ }^{11}$ ruling, California residents may peacefully exercise their right to free speech in parts of private shopping centres regularly held open to the public.

\subsection{South Africa}

It is clear that the Bill of Rights in South African Constitution follows the trend in international human rights documents, which restricts the right to freedom of expression of prohibiting the incitement of racial discrimination or racial hatred or hostility.

The applicable sections in the South African Constitution have been mentioned in the introduction to these findings. The right to the freedom of expression is firmly entrenched. ${ }^{12}$

\footnotetext{
${ }^{7}$ Handyside.

${ }^{8}$ Section 2(b).

${ }^{9} R$ v Zundel, 1992.

10 Miller.

11 Pruneyard case.

12 Section 16(1) of the Constitution.
} 
In Kauesa v Minister of Home Affairs ${ }^{13}$, a Namibian case, the case held that:

"In order to live and maintain a democratic state the citizens must be free to speak, criticize and praise where praise is due. Mutes silence is not an ingredient of a democracy because the exchange of ideas is essential to the development of democracy."

In addition, there are a number of academic writing and cases that have come before our courts in which the existence of that right has been reiterated.

Section (2) modifies that right in the manner spelt out by that subsection. Because this is an exception to the general and accepted rule that everyone has the right to freedom of speech, words such as "incitement" and "hate" need to be restrictively interpreted.

In considering the applicability of the expressions to the freedom of expression, the offending statement is looked at objectively. Two elements must be present before and expression can be determined to be as hate speech. Firstly, there must be an advocacy of hatred on one of the listed grounds (in case, it is race) and secondly there must be incitement to cause harm.

Put differently the enquiry is:

a. Does the statement advocate hatred; if so

b. Is such advocacy of hatred based on one of the grounds listed in the section, and,

c. Does such advocacy constitute incitement to cause harm?

Incitement, means to call for, urge or persuade. Burns (1991)14 quotes two South African decision relating to the Riotous Assemblies in which it was held that "incitement" connotes an element of persuasion by which some measure of reluctance or hesitation on the party incites is overcome. It must however, be borne in mind that section 16 (2) (c) ${ }^{15}$ deals with incitement to cause harm.

The concept of harm generally includes physical violence, and financial and emotional harm. The harm of hate speech matters to individuals, to the groups they belong to, to society generally, and to democracy. De Waal, Currie \& Erasmus $^{16}$ come to their conclusion despite the fact the categories listed in section 16 (2) $\odot$, constitute exceptions to the right conferred in section 16 (1) and that exceptions are usually restrictively interpreted.

The exercise of answering the above, could involve a single total analysis applying standards, criteria and benchmarks. Communicated in the case law, and as informed by International Instruments.

Justice Black, in Dennis vs. US ${ }^{17}$ said,

"To qualify to be categorized as hate speech, the objection must be based on more than fear, on more than passionate opposition against the speech on more than a revolted dislikes for its contents."

Section $16(10)^{18}$ of the South African Constitution provides for freedom of expression:

"Everyone has the right to freedom of expression, which includes -

a. freedom of the press and other media;

b. freedom to receive or impart information or ideas;

c. freedom of artistic creativity; and

d. academic freedom and freedom of scientific research.

Any limitation of this category of expression must satisfy the requirements of the general limitations clause contained in section $36(1)^{19}$, to be constitutionally valid.

Section 16(1) of the South African Constitution protects free expressive generally.

Freedom of expression does not extend to:

a. propaganda for war;

b. incitement of imminent violence; or

\footnotetext{
${ }^{13}$ Kauesa v Minister of Home Affairs.

14 Burns, 1991.

15 Section 16 (2) (c).

${ }^{16}$ De Waal, Currie \& Erasmus.

${ }_{17}$ Dennis vs. US.

18 Section 16(10).

19 Section 36(1).
} 
c. advocacy of hatred that is based on race, ethnicity, gender or religion, and that constitutes incitement that causes harm.

The internal limitation contained in section $16(2)^{20}$ has the effect that parliament can introduce hate speech legislation or by regulation for the class of speech listed in section 16(2). Such legislation would not be subject to a general limitation analysis in terms of section 36 . Since it would not amount to a limitation of the right contained in section 16(1). In short, a statute prohibiting hate speech as defined in the Constitution, cannot be subject to a freedom of expression challenge, because there is not constitutional right to speech of this nature.

Johannessen (1997:142) ${ }^{21}$ submits that section 16 (2) is a serious denigration of the right to freedom of expression which may be abused by governments to restrict speech. Hate speech ${ }^{22}$ is moved beyond the scope of constitutional scrutiny and of a general limitations analysis, and is moved into the area, of parliamentary supremacy.

Johannessen argues that if a person were to be prosecuted under a statute which targets speech within the ambit of section $16(2)^{23}$, he or she would not be able to rouse as a defense that the law is an unreasonable or unjustifiable restriction on the Constitutional freedom of expression, since there is no right that could be infringed. He or she could only try to prove that the words in question do not advocate hatred on the grounds listed in the Constitution.

Burns (199124 welcomes the internal limitation as a clear message to all living in South Africa that hate speech well not be tolerated. Hate speech is of nature insulting, degrading and of law value and do not advance any of the goals of freedom of expression. Hate speech, which is often suggested as synonymous with expressions of racial hatred and racism, has a destabilising and diverse effect on society. In encourages discrimination between groups which may lead to violence and a breakdown in public order. That is therefore that speech like "we will kill for Zuma" and "we will die and kill to defend Zuma" by leaders, cannot be tolerated in a society where speech should be free and not causing harm. From the same platform it was said that the government is the target of "people from the right and imperialists". The ANC youth leader's public attack on ministers during his speech at the Tswane University of Technology is another example of free speech that causes harm.

The Constitutional Court has recently emphasised the interest of the state in regulating hate speech, since hate speech may pose harm to the constitutionally mandated objective of building a non-racial and non-sexist society based on human dignity and the achievement of equality. (Feinberg, 1995)

According to section $16(2)^{25}$ of the Constitution the right to freedom of expression does not extend to

(1) advocacy of hatred that is based on race, ethnicity or religion, and

(2) that constitutes incitement to cause harm.

Both the above elements $p$ the advocacy of hatred and the incitement to cause harm, must be present before an expression ${ }^{26}$ will amount to advocacy of hatred or hate speech. The constitutional test whether speech is to be judged as hate speech, can therefore be considered to be a stringent one.

Ever since the first consideration of the idea of "free speech" it has been agreed that the right to free speech is subject to restrictions and exceptions. A well-known example is typified by the statement that free speech does not allow falsely "shouting fire in a crowded theatre"27. Other limiting doctrines, including those of libel and obscenity, can also recruit freedom of speech.

South African jurisprudence on hate speech. In Human Rights Commission of South Africa v SABC ${ }^{28}$ the Broadcasting Complaints Commission of South Africa (BCCSA) recently enquired whether the broadcast of the song "aman Ndiya" amounted to the advocacy of hatred based on race or ethnicity that constitutes incitement to harm, which is prohibited in terms of the Constitution and the Broadcasting Code. The broadcast of the song, and not the distribution of the CD or live performances of the song, was at state. The Human Rights Commission filed a complaint with the BCCSA on the basis that the song amounted to hate speech against Indians, a minority group of the South African population.

The BCCSA found that the broadcast of the song constituted hate speech as defined in section $16(2)^{29}$ of the

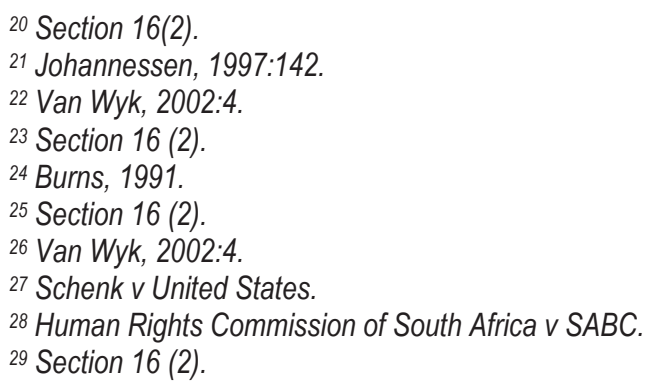


Constitution and in the Broadcasting Code. It found ${ }^{30}$ that the song promoted hate in sweeping, generalizing and emotive language and described Indians as a race as oppressive, humiliating and exploitive. It further found that he combination of the accusations constituted an incitement to harm and led to the inference by Indians their safety was at stake, that Indians were likely to fear for their security.

Although the court had little doubt that the song was racist, since it contrasts on race (Blacks) with another race (Indians), it emphasized that section 16(2) ${ }^{31}$ of the Constitution is not aimed at the advocacy of hatred based on race as such, but at advocacy of hatred based on race which also constitutes incitement to cause harm.

The harm cased by racism and xenophobia may not be immediate, and a specific action in and of itself may not even be sufficient to cause harm, but it is reasonable and foreseeable that harm is eventual and cumulative, which is why it is reasonable to make them illegal.

\section{Exceptions to Freedom of Expression}

Courts sometimes justify exceptions as speech which causes substantial harm to the public. The value of free speech sometimes clashes with other important values of culture.

Exceptions established by courts include the following:

- Defamation: Defamation consists of a publication of a statement of alleged fact which is false and which harms the reputation of another person. Our right to freedom of expression cause harm to another person.

- Causing panic: The example of speech which is not protected, because panic, is falsely shouting "fire" in a crowded theatre.

- Fighting words: In the famous case Chaplinsky vs. New Hampshire ${ }^{32}$, The US Supreme Court held that the First Amendment does not protect "fighting words" - those which by their very utterance inflict crying or tend to incite and immediate breach of peace ${ }^{33}$.

- Incitement to crime: It is a crime to incite someone else to commit a crime, and such speech is not protected.

- Obscenity: In Miller v California ${ }^{34}$ the US Supreme Court established a three-pronged test for obscenity prohibitions which would not violate the First Amendment:

a. whether the average person, applying contemporary community standards, would find that the work, taken as a whole, appeals to the prurient interest;

b. whether the work depicts or describes, in a patently offensive way, sexual conduct specifically defined by the applicable state law; and

c. whether the work taken as a whole, lacks serious literary, artistic, political or scientific value.

One controversy over the exception to free speech is whether obscenity causes real harm sufficient to justify suppression of free speech. Does viewing obscenity make it more likely that a man will later commit rape, or other acts of violence against women?

- Establishment of Religion: Some speech is restricted because it constitutes the establishment of religion. Prayer led by a principal in a public school would violate the establishment clause. Thus a school policy prohibiting the principal from leading such prayers would not violate the right of freedom of speech. This is controversial to some, who believes that banning prayers in public schools limits an equally important right, freedom of religion. This tension illustrates the not uncommon challenge of balancing competing and perhaps even irreconcilable values of the Constitution. Do teachers have free speech rights in schools? The discussion will briefly look at the situation in schools and how teachers exercise these rights.

\section{Free Speech Rights of Public School Teachers}

The Constitution protects all persons, no matter what their calling, including public school teachers. Nevertheless, because teachers are not only private citizens, but also agents of the state, courts have held that "the rights of the teachers in public schools are not automatically coextensive with the rights of adults in other settings".

\footnotetext{
30 Van Wyk, 2002:10.

31 Section 16(2).

32 Chaplinsky vs. New Hampshire.

${ }^{33}$ Baker, 1989.

34 Miller v California.
} 


\subsection{Speech outside of School}

Teachers do not forfeit the right to comment publicly on matters of public importance simply because they accept a public school teachers' position. Teachers cannot be fired or disciplined for statements about matters of public importance unless it can be demonstrated that the teacher's speech created a substantial adverse impact on school functioning. A teacher's off-campus statements regarding the war or participating in an off-campus political demonstration are not acceptable bases for job discipline or termination ${ }^{35}$.

The Supreme Court in the US recognizes three different types of forums when analyzing freedom of speech related to schools and teachers : public forum, limited public forum, and private forum. Public forums include areas such as sidewalks, common areas, and areas specifically designated free speech areas. Limited public forums include school grounds when opened for expression on a range of views, such as open meetings on public school grounds. The classroom is a private forum and as such, speech in the classroom can be limited in numerous ways ${ }^{36}$.

In Pickering v Board of Education ${ }^{37}$, a teacher was fired because he sent a letter to a local newspaper where he had criticized the Board of Education concerning past efforts to raise revenue for schools. The Court held that "a teacher's exercise of his right to speech on issues of public importance may not furnish the basis for his dismissal from public employment". The Court reasoned that because the letter concerned "a matter of public interest" and there was no evidence that it interfered with (1) his or her ability to perform classroom duties or (2) the regular operation of the school, the teacher's rights was no different than those of any other member of the general public. Thus, the teacher could not be dismissed for the exercise of his freedom of speech. Speech that harms where youth leaders of political parties and Cosatu leaders refer to the fact that they "will die for the revolution and that they are prepared to shoot and to kill" will certainly not help to encourage free speech in South Africa.

Teachers should also be free to attend church or otherwise discuss religion with learners' off-campus. No adverse employment decision, including demotions, reduction in salary or responsibilities, or even threats of discharge may be made because of a teacher's exercise of these rights.

\subsection{Speech Inside the Classroom}

A teacher appears to speak for the school district when he or she teaches, so the district administration has a strong interest in determining the content of the message its teachers will deliver. While courts sometimes protect the academic freedom of college and university professors to pursue novel teaching methods and curriculum, these principles do not apply with equal force to teachers. It does not violate a teacher's free speech rights when the district insists, for example, that she teaches physics and not political science, or that she cannot lead students in prayer - even though both have the result of limiting what the teacher says in the classroom.

Courts have upheld the authority of school districts to prescribe both course content and teaching. Courts in other jurisdictions have ruled that teachers have no free speech rights to include unapproved materials on reading lists ${ }^{38}$. (Baker, 1989:62).

Although the boundaries are not precise, there are limits to a school district's ability to control teachers' controversial speech in the classroom. Courts have sometimes ruled that schools may not punish teachers for uttering words or concepts in class that are otherwise consistent with the school curriculum, where the school has no legitimate pedagogical purpose for the restriction, or where the restriction harms student's ability to receive important ideas that are relevant to the curriculum.

A school district might choose not the include discussion about a controversial issue in its curriculum and direct teachers to avoid the topic unless it arises through student contributions to classroom discussion. Depending on the circumstances, a court might well approve such a rule. This assumes that the school is neutral in its implementation of the rule. If a school permits anti-war lesson plans but forbids pro-war lesion plans, such action would raise questions about viewpoint discrimination.

The school system does not "regulate" speech as much as it hires that speech. Expression is a teacher's stock in trade, the community she sells to her employer in exchange for a salary. A teacher hired to lead a social-studies class

${ }^{35}$ Curtis, 2000.

${ }^{36}$ Alexander \& Alexander, 1998:29.

${ }^{37}$ Pickering $v$ Board of Education.

38 Baker, 1989:62. 
can't use it as a platform for a revisionist perspective that Benedict Arnold wasn't really a traitor, when the approved program calls him one; a high-school teacher hired to explicate Moby-Dick in a literature class can't use Cry, The Beloved Country instead, even if Paton's book better suits the instructor's style and point of view; a mathematics teacher can't decide that calculus is more important than trigonometry and decide to let Hipparchus and Ptolemy slide in favour of Newton and Leibniz.

Basically, school administrations are allowed to restrict speech in the classroom based on a desire to present a unified message for the students. The rationale is that a teacher appears to speak on behalf of the administration when he or she teaches. Unlike other areas of speech, classroom speech can be limited to a certain viewpoint. An example involved a recent case in which a school governing body decided to promote Gay and Lesbian Awareness Month. One teacher made a bulletin board in his classroom that did not promote the message of tolerance and diversity. The bulletin board was found to conflict with the message presented by the administration. The court held that the teacher did not have a right to freedom of speech and had to remove the bulletin board 39 .

School administrations are allowed to limit speech in furtherance of school curriculum. If that is not a gray enough test, I am sure we could fuzz it up a little more. Suffice it to say that when confronted with a district-imposed restriction on speech, ask yourself whether the limitation has a reasonable relationship to a teaching purpose. The area that is more difficult is: when can a school district limit speech to a single viewpoint? For example, if a school district allows pro-war lesson plans, can it limit anti-war lesson plans? As the above case demonstrates, the answer depends on whether the limit is reasonably based on a purpose related to teaching.

\subsection{Teachers' Clothing}

In the landmark Tinker v. Des Moines ${ }^{40}$ Independent Community School District case, the U.S. Supreme Court established that public school students have the right to wear armbands in class as an expression of their views on topics of public concern. This right may be limited only if there is good reason to believe that the speech would cause a substantial and material disruption to education or violate the rights of others. Washington courts have not considered the question, but courts in other jurisdictions have differed over whether teachers have the same right as students to display personal political messages on their clothing. A court ruled that a New York teacher could not be fired for wearing a black armband in protest of the Vietnam War because the armband had caused no classroom disruptions, was not perceived as an official statement of the school, did not interfere with instruction, and did not coerce or "arbitrarily inculcate doctrinaire views in the minds of the students". On the other hand, in another case a court upheld a dress code that prevented teachers from wearing political buttons in the classroom because school districts have legitimate authority to "dissociate themselves from matters of political controversy"41.

Depending on the precise form of message displayed on the teachers' clothing, a school may have legitimate concern that a teacher's display of a political message is more likely than a student's to disrupt the school's intended educational message. For example, a school intending to educate students about the benefits of racial tolerance would find its message disrupted by a teacher wearing a Nazi-style armband with swastika.

Teachers should generally be free to wear clothing, jewelry, indicating their adherence to a religious faith, as long as the garb is not proselytizing or disruptive. Numerous courts have held that nuns could not be forbidden from wearing their habits while teaching in public schools. Similarly, teachers should be free to wear cross necklaces, inconspicuous WWJD (What will Jesus do) bracelets and yarmulkes. Merely employing an individual, who unobtrusively displays her religious adherence, is not tantamount to government endorsement of that religion, absent any evidence of endorsement or coercion. Nevertheless, items which convey advocacy for a particular religion, or particularly conspicuous religious garb that would disrupt the classroom environment, might still be constitutionally prohibited.

\subsection{Bulletin Boards}

Bulletin boards or similar spaces may be reserved for the school's own messaged and kept off-limits to the opposing

${ }^{39}$ Lyons, 1994:31.

40 Tinker v. Des Moines.

${ }^{41}$ Alexander \& Alexander, 1998. 
views of staff. ${ }^{42}$

But if a bulletin board is opened to public use, the school must remain neutral, allowing individual messages regardless of viewpoint

\subsection{On-Campus Conversations with Colleagues}

School administrators cannot impose overboard or viewpoint-based rules that restrict how teachers speak with each other during breaks or during casual conversations, unless it can be clearly shown that the speech would be harmful to workplace functioning.

\subsection{On-Campus Demonstrations or Meetings Open to the Public}

Public school property is often made available to community groups for meetings or demonstrations. The right of teachers to speak about matters of public concern should not be limited simply because the event they wish to speak is held on school grounds.

If the event appears to be more school-related than community-based (such as an anti-war rally attended only by students during the school day itself), a principal may be justified in considering teacher participation as part of the curriculum. Even for clearly non-curricular events, it may be desirable for teachers to make clear that they are participating as individuals and not as representatives of the school.

\subsection{Curriculum and Academic Freedom}

The authority to determine the content of courses taught in public schools generally lies with the school governing body. Thus, teachers may not override the authority of the school governing body by adding or omitting coursework from the prescribed curriculum. Nevertheless, the school governing body's authority to determine the curriculum is not absolute. For example, "school governing bodies may not fire teachers for random classroom comments." The Supreme Court has held that allowing school officials to completely exclude a particular subject from the classroom runs the risk of "cast[ing] a pall of orthodoxy over the classroom." Thus, the government may not prohibit the teaching of evolution, and it would likewise probably be prohibited from proscribing any mention of religion in the schools. As one court states, "[teachers] cannot be made to simply read from a script prepared or approved by the [school] board."

The Supreme Court in the US has recognized that a teacher's academic freedom is "a special concern of the First Amendment." Because school governing bodies retain authority to control the curriculum, a public school teacher's academic freedom is likely to be more limited than that of a college or university professor. Public school teachers possess some discretion in determining the methods of instruction that they use to teach the required curriculum. Thus, courts have held that teachers could not be dismissed for such methods as using a magazine survey that included items about sexually explicit matters in her high school speech and sociology classes or using a stimulation technique that evoked strong emotions on racial issues to teach about Reconstruction. At least where the teacher's chosen method of instruction does not cause substantial disruption in school order, interfere with others' rights, or affect the proscribed course content teachers have a modicum of discretion in choosing their instruction methods. ${ }^{43}$

\section{Conclusion}

The right of freedom of expression lies at the basis of a democratic society. Section 16(20) ${ }^{44}$ of the Constitution underlines this right and places certain forms of expression - including "hate speech" outside constitutional protection. Section $16(2)^{45}$ set a stringent test to be classified as hate speech.

The right to freedom of speech is not a right to cause others to live in fear of suffering harm. A decent person knows this and will not speak in ways that threaten others who, themselves, do not mean to do any harm.

Teachers do not unconditionally surrender their constitutional rights once they enter public education. Courts have determined, however that there are contexts in which these rights may be subject to limitations or must defer to other

\footnotetext{
42 Braun, 2004,91.

43 Sunstein, 1994:49.

${ }^{44}$ Section 16(20).

45 Section 16(2).
} 
interests. Unfortunately, teachers do not gain full protection for speech in the classroom or for speech related to personnel matters within the school.

\section{References}

Alexander, K, and Alexander, M. 1998. Teacher rights and freedoms. American Public School Law (4th ed, p632-645). Belmont, CA : Wadsworth.

Barkholder, Religious Rights of Teachers in Public Education, 18 Journal of Law and Education 335, 345 (1989).

Baker, E. 1989. Human Liberty and Freedom of Speech. Oxford : Oxford University Press.

Braun, S. 2004. Democracy off Balance : Freedom of Expression and Hate Propaganda Law in Canada. Toronto : University of Toronto Press.

Burns Suprema Lex : Essays on the Constitutional presented to Marinus Wiechers 3546.

Curtis, M.K. 2000. Free Speech, "The People's Darling privilege." Struggles for Freedom of Expression in American History. North Carolina : Duke University Press.

De Waal, J., Currie, I \& Erasmus, P. 2005. The Bill of Right handbook. Cape Town : Juta

Feinberg, J. 1995. Limits to the Free Expression of Opinion. California : Wadsworth Publishing Company.

Fish, S. 1994. There is no such thing as Free Speech and it's a good thing too. New York : Oxford University Press.

Jacobson, D. 1995. Freedom of Speech acts? A response to Langton. Philosophy and Public affairs 24, no 1.

Jacobson, D. 2000. "Mill on Liberty, Speech, and the Free Society" in Philosophy and Public Affairs, 29 no 3.

Johannessen, J. 1997. A critical view of the constitutional hate speech provision. South African Journal on human Rights. 1997. Vol 185, p137.

Lyons, D. 1994. Rights, Welfare, and Mill's Moral Theory. New York : Oxford University Press.

Mill, J.S. 1978. On Liberty - Indianapolis : Hackett Publishing press.

South Africa. 1996. The Constitution of South Africa, Act 106 of 1996, Pretoria : Government Printer.

Sunstein, C. 1994. Democracy and the Problem of Free Speech. New York : Free Press.

Van Wyk, C. 2002. The Constitutional treatment of hate speech in South Africa. Paper read at the Congress of the International Academy of Comparative Law. Bashane 14-20 July 2002.

\section{Court Cases}

Chaplinsky vs New Hampshire, 315 US, 568, 572 (1942)

Human Rights Commission of South Africa v SABC Case No :31/2002

Kausa v Minister of Home Affairs Namibia

R v Keegstra. SCR 227-228 (1990)

Miller v California, 413 US. 15,24 (1973)

Pickering v Board of Education,391 US 563 (1968)

Schenk v United States, 354 US. 476,512 (1959)

Tinker v Des Miones Indep Cmty. Sch. Distr., 393 US 503, 506 (1969) 